\title{
Assessment of impact of fishing on Indian mackerel Rastrelliger kanagurta (Cuvier, 1816) in Tuticorin, south-east coast of India
}

\author{
M. SIVADAS, S. MOHAMED SATHAKKATHULLAH, K. SURESH KUMAR AND K. KANNAN \\ Tuticorin Research Centre of ICAR-Central Marine Fisheries Research Institute, Tuticorin - 628 001, Tamil Nadu, India \\ e-mail: sivadasmadhav@yahoo.com
}

\begin{abstract}
Fishery of the Indian mackerel Rastrelliger kanagurta (Cuvier, 1816) from Tuticorin was studied for the period 2011-2014. Indian mackerel formed fishery round the year in Tuticorin with peak during June to November in trawl and October to December in gillnet. The annual catch varied from 1650 to $5101 \mathrm{t}$ (average $2968 \mathrm{t}$ ) in gillnet and from 815 to $1716 \mathrm{t}$ (average $1231 \mathrm{t}$ ) in trawl. Total length (TL) of the fishes ranged from 10 to $30.5 \mathrm{~cm}$. Length-weight relationship estimated was $\mathrm{W}=0.0038777^{*} \mathrm{~L}^{3.3}\left(\mathrm{r}^{2}=0.99\right.$, $\mathrm{n}=535, \mathrm{~L}=\mathrm{TL}$ in $\mathrm{cm}, \mathrm{W}$ in $\mathrm{g}$ ). The fishes were found to be continuous spawners with peak spawning during January to August and November. The von Bertalanffy growth equation derived was $\left.\mathrm{Lt}=31.2\left[1-\mathrm{e}^{-1.3(\mathrm{t}+t)}\right)\right]$. The species attained TL of $22.7 \mathrm{~cm}$ in 12 months and $28.9 \mathrm{~cm}$ by the end of second year. Longevity estimated was 2.3 years, Phi-prime index ( $($ ) was 7.143 , while $\mathrm{Z}$ and $\mathrm{M}$ were 4.36 and 2.132 respectively. Thompson and Bell model showed continuous increase of yield even after considerable rise in F-factor. Spawning stock biomass (SSB) was 79\% at an f-factor of 3.5. $\mathrm{F}_{0,1}$ using Beverton and Holt Y/R model was 3.4 whereas the present $\mathrm{F}$ was 2.23 indicating that the current level of fishing is not affecting the stock adversely.
\end{abstract}

Keywords: Age and growth, Gonado-somatic index, Indian mackerel, Maturity, Rastrelliger kanagurta, Thompson and Bell model

\section{Introduction}

Indian mackerel Rastrelliger kanagurta (Cuvier, 1816) constitutes an important fishery in Tamil Nadu and in Tuticorin, it forms a regular fishery contributing around $5.8 \%$ of the total landings. Mackerel landings at Tuticorin for the period 1997-2007 varied between 411 and 2038 t (Abdussamad et al., 2010). Marine fisheries are highly dynamic and are under constant change in terms of magnitude of landing, seasonal fluctuation, changes in recruitment and biology and hence, monitoring of the resource characteristics and its exploitation is vital for better management of the resources. The present study deals with the fishery, biology and stock characteristics besides the impact of fishing on Indian mackerel based on data collected during the period 2011-2014 from Tuticorin, south-east coast of India.

\section{Material and methods}

Data on catch and effort were obtained from Fishery Resources Assessment Division of ICAR-Central Marine Fisheries Research Institute (ICAR-CMFRI), Kochi. Biological data were collected from important landing centres (Tuticorin Fishing Harbour and Punnakayal landing centre) in Tuticorin, once a week and analysed in the laboratory for size range, maturity and fecundity. For biological aspects like maturity, sex ratio, gonado-somatic index and size at first maturity, 8118 numbers of $R$. kanagurta were studied. For fecundity estimation, 754 ovaries were used from different size groups. Length frequency was determined from 10244 samples. Maturity stages were studied following the classification of Rao (1962). Besides the spent stage VII, an additional partially spent (VIIa) stage was also included. In partially spent condition, the ovary is reduced in size and weight but contained healthy transparent ova as observed by Yohannan and Abdurahiman (1998). In partially spent males, the testis is white in colour with reduced size but on slight pressure, milt oozes out. Fecundity was estimated by gravimetric method and relative fecundity was derived by dividing the absolute fecundity with the body weight. Ova diameter was measured under microscope using the Swift cam software, with a view to understand the monthly occurrence of mature ovaries. Size at first maturity was estimated following King (1996) for pooled data as there was no clear difference in the size between male and female). Length-weight relationship was derived as in Le Cren (1951). Regression analysis was carried out on the relation of fecundity to total length, body weight, ovary weight and relative fecundity. The relationship between fecundity and total length of fish was determined using the formula $\mathrm{F}=\mathrm{aL}^{\mathrm{b}}$ where $\mathrm{F}=$ fecundity, $\mathrm{L}=$ total length, $\mathrm{a}=$ constant and $\mathrm{b}=$ regression coefficient. For other variables, the relationship was derived using the formula $\mathrm{Y}=\mathrm{a}+\mathrm{bX}$, where $\mathrm{Y}=$ fecundity and $\mathrm{X}=$ other variables and ' $\mathrm{a}$ ' and ' $b$ ' are constant and coefficient respectively. Significance of correlation was tested using the SPSS statistical package. Chi-square $\left(\chi^{2}\right)$ was applied to find out whether the 
observed sex ratios were significantly different from the expected 1:1 ratio. Gonado-somatic index (GSI) for pooled data (monthly average) was estimated using the formula GSI $=\mathrm{Wg}^{*} 100 / \mathrm{W}$, where $\mathrm{Wg}=$ weight of gonad and $\mathrm{W}=$ weight of fish. The pooled monthly length frequency samples were used to convert the monthly catch in weight into catch in numbers and this was used for studies on growth, mortality, virtual population analysis (VPA) and Thompson and Bell analysis. Growth parameters like asymptotic length $\left(\mathrm{L}_{\infty}\right)$ and growth coefficient $\mathrm{K}$ were estimated using PowellWetherall plot (Wetherall et al., 1987) and ELEFAN I module of the FiSAT software. The length based growth performance index, phi prime ( $Q$ ) was calculated from $\mathrm{L}_{\infty}$ and $\mathrm{K}$ as in Pauly and Munro (1984). Longevity was estimated as $\mathrm{t}_{\max }=3 / \mathrm{k}+\mathrm{t}_{\mathrm{o}}$ (Pauly, 1984). Natural mortality (M) was calculated using Pauly's empirical formula (Pauly, 1980) taking mean temperature as $28^{\circ} \mathrm{C}$ and total mortality $(\mathrm{Z})$ from length converted catch curve (Pauly, 1983). The fishing mortality (F) was determined by subtracting $M$ from $Z$. The exploitation rate $(E)$ was calculated using the formula $\mathrm{E}=\mathrm{F} / \mathrm{Z}$, where $\mathrm{F}=$ fishing mortality and $\mathrm{Z}=$ total fishing mortality. Length structured VPA was used to find out the fishing mortality per length class besides the recruitment numbers. Thompson and Bell model was employed to estimate maximum sustainable yield (MSY) besides impact of fishing on the stock (Sparre and Venema, 1992) and Beverton and Holt (1957) yield per recruit model was used to estimate $\mathrm{F}_{0.1}$.

\section{Results}

\section{Fishery}

Indian mackerel was landed mainly by gillnet (55-60 mm mesh size) and trawl, which together accounted for around $98 \%$ of the total mackerel catch from Tuticorin. Catch by gillnet ranged from $1650 \mathrm{t}$ in 2014 to $5101 \mathrm{t}$ in 2011 with an average of $2968 \mathrm{t}$ and accounted for more than $68 \%$ of total catch. Catch per unit effort (CPUE) showed a progressive reduction from $17.9 \mathrm{~kg}$ in 2011 to $6.7 \mathrm{~kg}$ in 2014 with an average of $12.6 \mathrm{~kg}$. In trawl, the catch increased from $815 \mathrm{t}$ in 2011 to $1716 \mathrm{t}$ in 2014 with an average of $1231 \mathrm{t}$ with a corresponding increase in CPUE from $24.1 \mathrm{~kg}$ in 2011 to $45.3 \mathrm{~kg}$ in 2014 with an average of $32.4 \mathrm{~kg}$ (Table1).

Average monthly catch of mackerel in trawl varied from $22.5 \mathrm{t}$ in April to $230 \mathrm{t}$ in June, June to November formed the most productive period (Fig.1). The highest CPUE was recorded in November $(49.1 \mathrm{~kg})$ followed by October $(41.1 \mathrm{~kg})$ and June $(39 \mathrm{~kg})$. Average monthly catch in gillnet varied from $57.7 \mathrm{t}$ in September to $673.6 \mathrm{t}$ in November with October to December being the most productive period (Fig. 1). CPUE ranged from $4.1 \mathrm{~kg}$ in March to $28.2 \mathrm{~kg}$ in November with higher CPUE (23.3 to $28.2 \mathrm{~kg}$ ) during October - December.

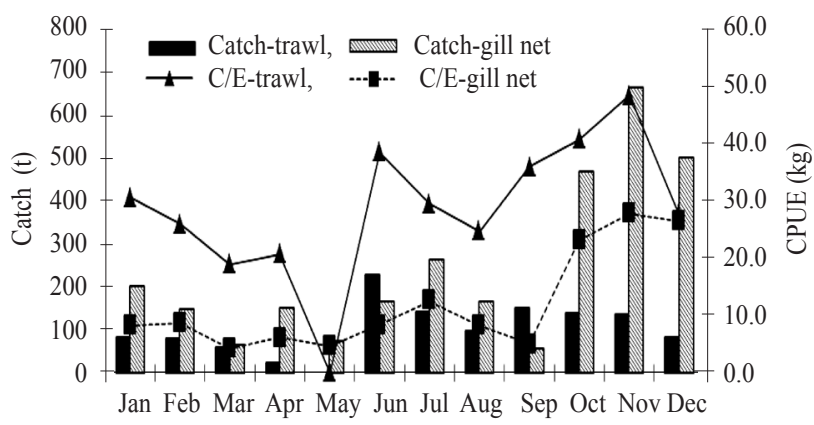

Fig. 1. Average gear-wise seasonal landing of R. kanagurta in tuticorin during 2011-14

\section{Length composition}

Total length ranged from 12 to $30 \mathrm{~cm}$ in gillnet whereas in trawl, it was 10 to $30.5 \mathrm{~cm}$ (Fig. 2). There were no large scale recruitment of juveniles and the mean and modes were 21.8 and $23 \mathrm{~cm}$ in gillnet and in trawl $22.8 \mathrm{~cm}$ and $22 \mathrm{~cm}$ respectively. On an average, the adult fishes formed bulk of the catch in both gillnet and trawl. In gillnet, $84 \%$ of the size groups were above the size at first maturity $\left(\mathrm{L}_{\mathrm{m}}\right)$. Size groups 19.5 to $26 \mathrm{~cm}$ formed $77 \%$ of the total size groups landed.

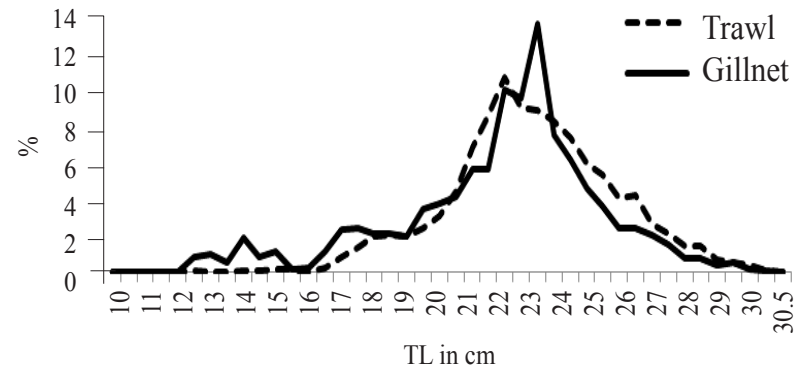

Fig. 2. Average annual length composition of $R$. kanagurta in tuticorin during 2011-14

Table 1. Catch, effort and CPUE of R. kanagurta and \% in total catch from Tuticorin

\begin{tabular}{|c|c|c|c|c|c|c|c|c|}
\hline & \multicolumn{3}{|c|}{ Trawl } & \multicolumn{3}{|c|}{ Gillnet } & \multirow{2}{*}{ Total mackerel catch $(\mathrm{kg})$} & \multirow{2}{*}{$\%$ in total catch } \\
\hline & $\mathrm{E}$ (units) & $\mathrm{C}(\mathrm{kg})$ & CPUE (kg) & $\mathrm{E}$ (units) & $\mathrm{C}(\mathrm{kg})$ & CPUE (kg) & & \\
\hline 2011 & 33770 & 815349 & 24.1 & 285586 & 5100670 & 17.9 & 6080888 & 7.9 \\
\hline 2012 & 42269 & 1524573 & 36.1 & 214203 & 3251792 & 15.2 & 4870013 & 7.4 \\
\hline 2013 & 37967 & 867330 & 22.8 & 196614 & 1869828 & 9.5 & 2787609 & 3.5 \\
\hline 2014 & 37841 & 1716075 & 45.3 & 246132 & 1650790 & 6.7 & 3499502 & 4.8 \\
\hline $\begin{array}{l}\text { Average } \\
\%\end{array}$ & 37962 & $\begin{array}{l}1230832 \\
28.6\end{array}$ & 32.4 & 235634 & $\begin{array}{l}2968270 \\
68.9\end{array}$ & 12.6 & 4309503 & 5.8 \\
\hline
\end{tabular}


In trawl, $94 \%$ of the total size groups caught was above size at first maturity and $85 \%$ of the catch were in the range 19.5 to $26.5 \mathrm{~cm}$. The length-weight relationship was derived as: $\mathrm{W}=0.0038777^{*} \mathrm{~L}^{3.3}\left(\mathrm{r}^{2}=0.99, \mathrm{n}=535\right)$.

\section{Reproductive biology}

Partially and fully spent stages were observed in both the sexes throughout the year and they dominated during most of the months (Fig. 3). Ova size greater than $800 \mu \mathrm{m}$, considered as large were transparent and were found throughout the year (Fig. 4). But ova of $>1000 \mu \mathrm{m}$ in dia were more pronounced during January to August and also in November.

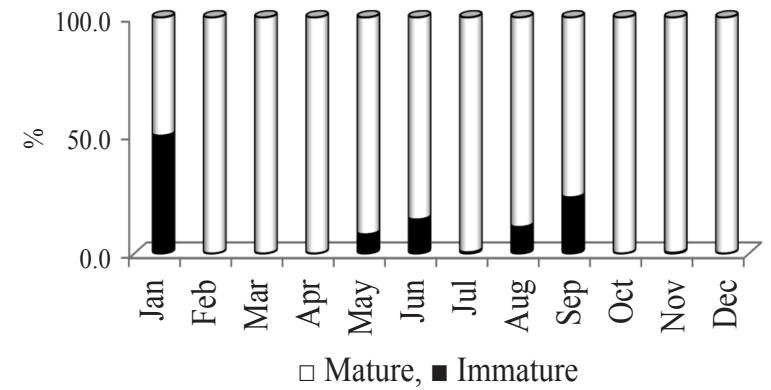

Fig. 3. Average monthly maturity condition of $R$. kanagurta landed in tuticorin during 2011-14

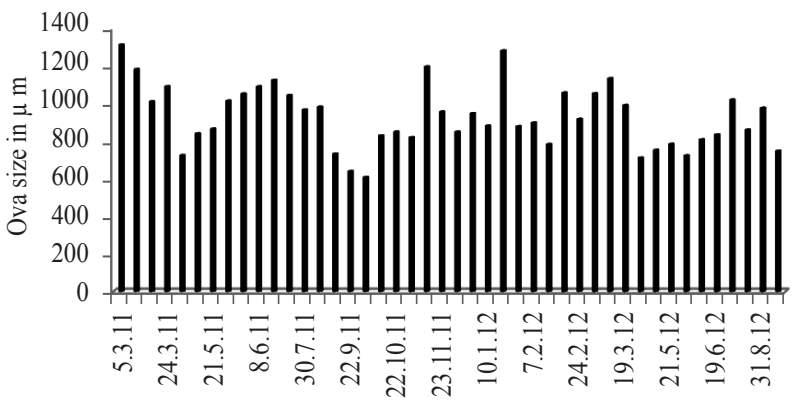

Fig. 4. Ova diameter of R. kanagurta
Gonado-somatic index (Fig. 5) showed higher values during July-August. Sex ratio did not show any pattern of dominance (Table 2). However, the ratio was found to be significant at $5 \%$ level in most of the months in different years.

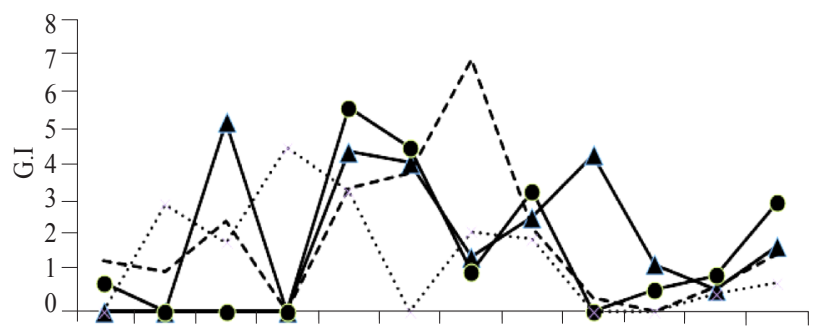

Jan Feb Mar Apr May Jun Jul Aug Sep Oct Nov Dec

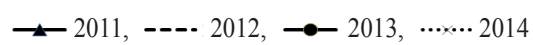

Fig. 5. Gonado-somatic index of R. kanagurta (sexes pooled)

Fecundity varied from 38751 to 1.18 lakhs and the relation between fecundity and other variables are as follows:

$$
\begin{aligned}
\mathrm{F}= & 0.981645+1.5951 \mathrm{Log} \mathrm{L}(\mathrm{r}=0.38 \mathrm{~N} . \mathrm{S}) \text {, where } \mathrm{F} \text { and } \\
& \mathrm{L} \text { are fecundity and total length respectively. } \\
\mathrm{F}= & 29720.35+206.4453 \mathrm{~W}(\mathrm{r}=0.43, \mathrm{p}<0.05 \text { level }) \text {, where } \\
\mathrm{W}= & \text { weight of fish } \\
\mathrm{F}= & 39833.34+2655.93 \mathrm{G}(\mathrm{r}=0.49, \mathrm{p}<0.05 \text { level }) \text {, where } \\
\mathrm{G}= & \text { ovary weight } \\
\mathrm{F}= & 18237.38=131.1486 \mathrm{RF}(\mathrm{r}=0.69, \mathrm{p}<0.01 \% \text { level }) \text {, where } \\
\mathrm{RF}= & \text { Relative fecundity }
\end{aligned}
$$

\begin{tabular}{|c|c|c|c|c|c|c|c|c|}
\hline \multirow{2}{*}{ Trawl } & \multicolumn{2}{|r|}{2011} & \multicolumn{2}{|r|}{2012} & \multicolumn{2}{|c|}{2013} & \multicolumn{2}{|c|}{2014} \\
\hline & Sex ratio & $\sum 2$ value & Sex ratio & $\sum 2$ value & Sex ratio & $\sum 2$ value & Sex ratio & $\sum 2$ value \\
\hline Jan & No data & & 1 & 0.001 & 1.1 & 0.20 & & \\
\hline Feb & No data & & 1.5 & 2.4 & No fishery & & 0.8 & 1.4 \\
\hline Mar & 1.5 & 0.6 & 2.1 & $5.1^{*}$ & No fishery & & 0.5 & $7 *$ \\
\hline Apr & 0.6 & 2.5 & 0 & 0 & No fishery & & 0.7 & 3.24 \\
\hline May & 0.6 & 2.2 & 1 & 0.006 & 0.7 & 0.80 & 0.8 & 1.4 \\
\hline Jun & 0.7 & 3.4 & 1.5 & 2.2 & 1 & 0.50 & & \\
\hline Jul & 0.9 & 0.4 & 1 & 0.006 & 0.68 & 2.30 & 0.9 & 0.09 \\
\hline Aug & 1.2 & 0.4 & 0.5 & 3.6 & 2.7 & $6.2^{*}$ & 1.4 & $6.2^{*}$ \\
\hline Sep & 0 & 0.5 & 0.9 & 0.14 & 0 & 0.00 & & \\
\hline Oct & 0.7 & 3 & 0 & 0 & 3 & $13.9^{*}$ & & \\
\hline Nov & 0.7 & $3.8^{*}$ & 1.2 & 1.1 & 2 & $6.3^{*}$ & 0.8 & 1.3 \\
\hline Dec & 0 & 0 & 0.5 & $4.2^{*}$ & 1.1 & 0.09 & 3.3 & $80.6^{*}$ \\
\hline
\end{tabular}

Size at first maturity (pooled) was $19.5 \mathrm{~cm} \mathrm{TL} \mathrm{(Fig.} \mathrm{6).}$ However the minimum size at which mature fish were observed was $16.7 \mathrm{~cm}$.

Age and growth

$\mathrm{L}_{\infty}$ obtained by Powell-Wetherall method $(30 \mathrm{~cm}$ TL) was further refined using ELEFAN I which gave $\mathrm{L}_{\infty}$ as $31.2 \mathrm{~cm}$ and $\mathrm{K} 1.3 \mathrm{y}^{-1}$, $\left(\mathrm{t}_{0}\right.$ was assumed as 0$)$. On the basis of

Table 2. Sex ratio of $R$. kanagurta (taking male as 1)

${ }^{*} \mathrm{p}<0.05$ level 


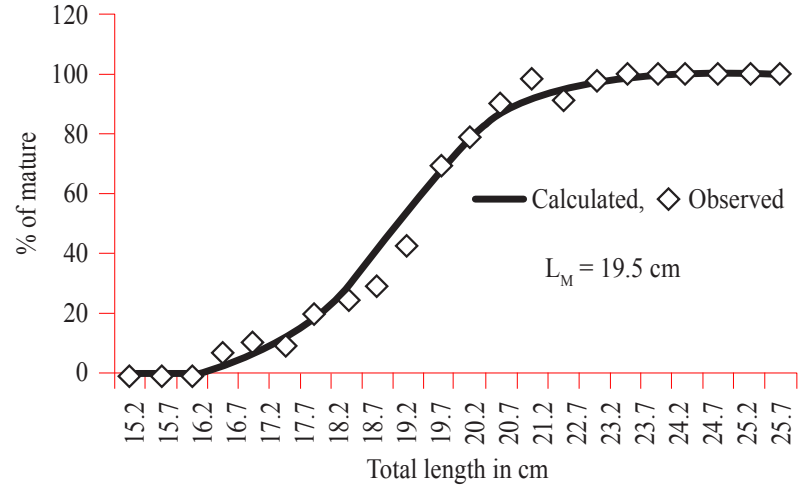

Fig. 6. Size at first maturity of R. kanagurta

von Bertalanffy growth equation - Lt $=31.2\left[1-\mathrm{e}^{-1.3(\mathrm{t}+\mathrm{t} 0)}\right]$ the species was found to grow $22.7 \mathrm{~cm}$ in 12 months and $28.9 \mathrm{~cm}$ by the end of second year.

The longevity of the species was 2.3 years, $\mathrm{W}_{\infty}$ (asymptotic weight) $331 \mathrm{~g}$ and phi-prime estimated index $(\varphi)$ was 7.143.

\section{Mortality}

Total mortality $(Z)$ was estimated as 4.36 by the length converted catch curve method. Natural mortality (M) and fishing mortality (F) were 2.132 and 2.23 respectively. The $\mathrm{M} / \mathrm{K}$ value and exploitation rate (E) were 1.64 and 0.51 respectively. From the VPA analysis, it is observed that the fishing mortality increased from the size group $22 \mathrm{~cm}$ onwards.

\section{Prediction analysis}

Thompson and Bell model revealed the yield and value (economic yield) to continuously rise with every increase of F-factor implying that the present fishing has not affected the stock adversely (Fig.7). Moreover the spawning stock biomass even at an f-Factor of 3.5 was $79 \%$ of the virgin spawning stock biomass which gives further credence to the observation that the present fishing level is not affecting the stock adversely.

The $\mathrm{F}_{0.1}$ estimate was 3.4 which was more than the present fishing mortality of 2.23 (Fig. 8) which also indicates that the present fishing is at safe level.

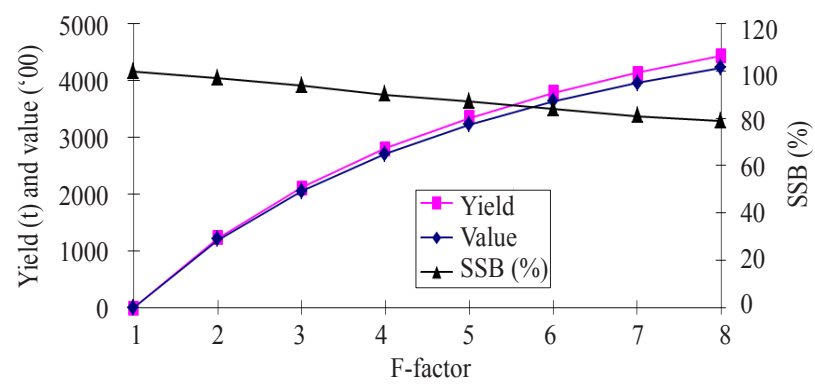

Fig. 7. Yield, value and SSB (\%) for various levels of F-factor

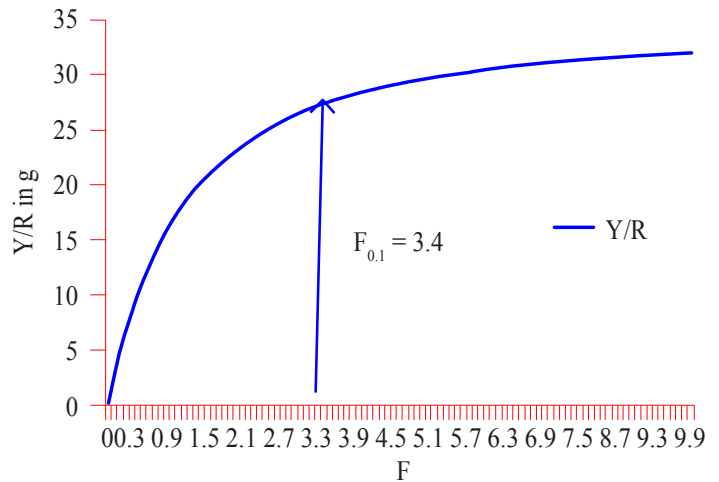

Fig. 8. $\mathrm{Y} / \mathrm{R}$ and $\mathrm{F}_{0.1}$ of $R$. kanagurta

\section{Discussion}

In Tuticorin, Indian mackerel formed a fishery throughout the year during 2011-2014 with peak from June to November in trawl and October to December in gillnet which is almost in conformity with the observation by Abdussamad et al. (2010) who reported peak fishery from June to August in trawl and November to December in gillnet. Trawl nets are operated during day time extending till sunset whereas gillnets are operated from midnight to early morning. Compared to the period 1997-2007, there was substantial increase in the contribution by trawl as the present average contribution by trawl was $29 \%$ as against $17 \%$ earlier. The increase in the size of the boat, engine power and also operation of specific gears like ayilavala (gillnet) targeting mackerel could be the reasons for the increased landing compared to previous years. More than $77 \%$ of catch in gillnet and more than $85 \%$ in trawl were accounted by the size groups between 19.5 and $26 \mathrm{~cm}$ which suggest that these fishes would get an opportunity to breed and spawn at least once before being caught. Dominance of partially spent or fully spent ovaries throughout the year suggests continuous spawning with peak during January to August and November. According to Balakrishnan and Rao (1967), the ripe intra-ovarian egg of Indian mackerel has a diameter of 0.85 to $0.94 \mathrm{~mm}$ and possesses a single oil globule measuring $0.23 \mathrm{~mm}$. In the present observation, the intra-ovarian eggs of diameter more than $0.8 \mathrm{~mm}$ were found throughout the year. Eggs above $1 \mathrm{~mm}$ dia were found during January to August and also in November. This further fortifies the observation of continuous spawning. Abdussamad et al. (2010) also observed continuous spawning of $R$. kanagurta from Tuticorin with peak during January-April. Radhakrishnan et al. (1991) opined that it spawns in Madras during May-June. Girijavallabhan and Gnanamuthu (1974) observed March-May as the spawning season of mackerel off Madras coast. In Visakhapatnam, February-June is reported as the major spawning period followed by a shorter minor peak during August- September with October-December being the period of low spawning 
activity (Luther, 1995). However, Rao (1962) concluded that the species spawn during October-April coinciding with the north-east monsoon at Visakhapatnam and the general period of occurrence of juvenile mackerel along the east coast of India is from March to August. From Kakinada, Abdussamad et al. (2006) also observed round the year spawning with peak during December-January. In Tuticorin, the fishery was sustained by adult fishes. The occurrence of larger size groups of 29 to $30 \mathrm{~cm}$ in the fishery for three to four months every year indicates positive signs of the stock, as such groups do not form the fishery in other areas of east coast and also in most of the areas along the west coast of India. Driftnets operated in the 18-25 fathom off Vizhinjam during the months of October-April capture fairly large sized mackerel ranging from $24-32 \mathrm{~cm} \mathrm{TL}$, which are reported to spawn in the waters off Vizhinjam from October until the end of February (Rao, 1962). Size at first maturity of $19.5 \mathrm{~cm}$ estimated during the present study is slightly higher than that estimated by Abdussamad et al. (2010) who reported 18.4 $\mathrm{cm}$ for males and $18.8 \mathrm{~cm}$ for females. Full gonadal maturity has been reported at a much smaller size of $17 \mathrm{~cm}$ onwards (Abdussamad et al., 2010). In the present study also, mature fishes were seen from $16.5 \mathrm{~cm}$ onwards.

The present study reveals that the species has longevity of 2.3 years, maturing at around 9 months. According to Beverton and Holt (1959), M/K ratio generally ranges from 1-2.5 and hence 1.64 obtained in the present study very well conforms to this. The fact that the yield and value (economic yield) increased with every increase in the F-factor indicate that the present fishing does not have any adverse effect on the resource. The high percentage of SSB found even after substantial increase of F-factor further supports that the stock is healthy. $\mathrm{F}_{0.1}$ estimated by Beverton and Holt analysis was well above the current fishing level which also highlights the health of the resource. Since the traditional fishermen use different types of gear depending on the availability and abundance of particular resource or target fishes of local importance, the fishing may not always give a true picture of abundance of mackerel. In the case of trawl fishery also, mackerel forms part of bycatch and hence the catch need not always reflect true abundance of the resource. Inspite of these facts, the present study clearly shows that the current level of fishing is not affecting the resource adversely.

\section{Acknowledgements}

The authors express their sincere gratitude to the Director, ICAR-CMFRI, Kochi for all the encouragement. The authors thank Dr. Prathibha Rohit, Head-in-charge, Pelagic Fisheries Division, ICAR-CMFRI for the kind perusal of the manuscript and necessary corrections. We also thank ICAR funded NICRA project for financial support.

\section{Reference}

Abdussamad, E. M., Mohamed Kasim, H. and Achyya, P. 2006. Fishery and population characteristics of Indian mackerel, Rastrelliger kanagurta (Cuvier) at Kakinada. Indian J. Fish., 53(1): 77-83.

Abdussamad, E. M., Pillai, N. G. K. Mohamed Kasim, H., Habeeb Mohamed, O. M. M. J. and Jeyabalan. K. 2010. Fishery, biology and population characteristics of the Indian mackerel, Rastrelliger kanagurta (Cuvier) exploited along Tuticorin coast. Indian J. Fish., 57(1): 17-21.

Balakrishnan,V. and Rao, K. V. N. 1967. Some post-larval and juvenile stages of Indian mackerel, Rastrelliger kanagurta (Cuvier ) with notes on the changes in body form. Indian J. Fish., 14(1\&2): 97-114.

Beverton, R. J. H. and Holt, S. J. H. 1957. On the dynamics of exploited fish populations. Fish. Inves. Minist. Agric. Fish. Food. G. G. (2 Sea Fish), 19: 553 pp

Girijavallabhan, K. G. and Gnanamuthu, J. C. 1974. On a mackerel larvae ( Rastrelliger sp.) from the inshore waters of Madras. Indian J. Fish., 21: 293-294.

Gopakumar, G., Pillai, N. G. K. and Omana, T. A. 1991. The fishery characteristics and biology of mackerel at Vizhinjam. J. Mar. Biol. Ass. India, 33(1 \&2): 107-114.

King, M. 1996. Fisheries biology, assessment and management. Fishing News Books, Oxford, 341 pp.

Le Cren, E. D. 1951. The length-weight relationship and seasonal cycles in gonadal weight and condition in the perches (Perca fluviatilis). J. Anim. Ecol., 20: 201-219.

Luther, G. 1995. Fishery and resource characteristics of mackerel of Visakhapatnam coast. Mar. Fish. Infor. Serv. $T \&$ E. Ser., 138: $1-5$.

Pauly, D. 1980. On the interrelationships between natural mortality, growth parameters and mean environmental temperature in 175 fish stocks. J. Cons. CIEM, 39(3): 175-192.

Pauly, 1983. Length converted catch curves; A powerful tool for fisheries research in tropics (Part II). Fish byte, 2(1): 17-19.

Pauly, D. 1984. Some simple methods for the assessment of tropical fish stocks. FAO Fisheries Technical Paper, 240: 54 pp.

Pauly, D and. Munro, J. L. 1984. Once more on the comparison of growth in fish and invertebrates. ICLARM Fish byte, 2(1): 21.

Radhakrishnan, N. S., Vivekanandan, E. and Kuthalingam, M. D. K.. 1991. Some observations on the mackerel fishery resources of Madras coast. J. Mar. Biol. Ass. India, 33(1 \&2): 55-58.

Rao, K. V. N. 1962. Observation on the bionomics of Indian mackerel, Rastrelliger kanagurta (Cuvier), caught in Lawsens Bay near Waltair, Andhra coast. Proc. Symp. Scombroid Fishes, Part II, p. 574-585. 
Rao, K. V. N. 1962. Food of the Indian mackerel, Rastrelliger kanagurta (Cuvier) taken by drift nets in the Arabian Sea off Vizhinjam, South Kerala. Indian J. Fish., 9A(2): 530-541.

Sparre, P. and Venema, S. C. 1992. Introduction to tropical fish stock assessment, Part-1-Manual. FAO Fisheries Technical Paper, 306(1): $376 \mathrm{pp}$.
Wetherall, J. A., Polovina, J. J. and Ralston, S. 1987. Estimating growth and mortality in steady state fish stocks from length-frequency data. ICLARM Conf. Proc., 13: 53-74.

Yohannan, T. M. and Abdurahiman, U. C. 1998. Maturation and spawning of Indian mackerel. Indian J. Fish., 45(4): 399-406.

Date of Receipt : : 03.06.2016

Date of Acceptance : 07.09.2016 